\title{
Recent Trend in Ozone Levels in the Metropolitan zone of Mexico City
}

\author{
Javier Audry Sánchez, and Francisco Javier Garfias Ayala
}

Facultad de Química. Departamento de Fisicoquímica. Universidad Nacional Autónoma de México. México, D.F. 04510 México jgarfias@servidor.unam.mx

Received January 24, 2008; accepted December 2, 2008

\begin{abstract}
Ozone concentration in the atmosphere of Mexico City is analyzed for the period 2000-2006, finding an average reduction of $24 \%$, in spite of not meeting the norm of $110 \mathrm{ppb}$ in more than $42 \%$ of the days in Pedregal. The maximum ozone levels in the last three years were $250 \mathrm{ppb}$ well above the norm of $110 \mathrm{ppb}$. The number of vehicles registered in the Federal District has increased in the period by an average of $35 \%$. Notwithstanding the increase in vehicular fleet, improvement of air quality is ascribed to the replacement of old cars by more efficient and less contaminating new cars. To decrease even more the ozone concentration, it is suggested to decrease further the Reid Vapor Pressure of gasoline to 7.0 psia to reduce the evaporation of light olefins.
\end{abstract}

Keywords: Ozone, replacement of old cars by new ones, daily emission

\section{Introduction}

Garfias and Díaz [1] analyzed the trend in ozone levels from 1986 to 2000, finding that the worst year was 1991, when a peak of $404 \mathrm{ppb}$ was reached. Since then, ozone levels were substantially decreased to a maximum of $282 \mathrm{ppb}$ in 2000. However, as in 2000 the ozone concentration did not decreased as consistently as previously, it was feared that the increment in the vehicular fleet and its consequent increase in vehicular emissions would deteriorate air quality in the Valley of Mexico. To study data, they found that the universe made by the following five stations: Tlalnepantla, Xalostoc, Merced, Pedregal and Cerro de la Estrella, when ozone data was grouped yearly can be studied statistically. They concluded that the year with the highest ozone level and the higher standard deviation was 1991, year which was taken as reference thereafter to make comparisons on the efficiency of the municipal programs to reduce ozone levels. Furthermore, they observed an average reduction in the ozone levels of $34.4 \%$ on the group of the five stations in 1999 among the percentiles 5 and $95 \%$ with respect to 1991, reduction that increases as the percentile is smaller. They also found that in the years of the ninety decade of last century, the maximum daily ozone concentration was reduced year by year, with the exception of 2000. Comparing the ozone levels of 2000 with respect to 1999 , there was a reduction in the lower percentiles but not in the higher ones. In 1991 only $22.7 \%$ of the measurements complied with the norm in the five stations, while in 1999 the satisfactory maximum daily ozone measurements raised to $55 \%$, and consequently it was affirmed
Resumen. Se analiza la concentración de ozono en la atmósfera de la Zona Metropolitana de la Ciudad de México durante el período 2000-2006, encontrando una reducción promedio de $24 \%$, a pesar de que no se cumple con la norma de 110 ppb en más de $42 \%$ de los días en la estación de Pedregal. El máximo nivel de ozono en los últimos tres años fue de $250 \mathrm{ppb}$, arriba de la norma de $110 \mathrm{ppb}$. El número de vehículos registrados en el Distrito Federal tuvo un incremento promedio en el periodo de $35 \%$. A pesar del incremento vehicular, la mejoría en la calidad del aire se adscribe al remplazo de vehículos viejos contaminantes por más eficientes y menos contaminantes vehículos. Para disminuir aún más los niveles de ozono se propone reducir la presión Reid de la gasolina a 7 psia, lo cual reduciría la evaporación de las olefinas ligeras.

Palabras clave: Ozono, remplazo de vehículos viejos por nuevos, emisión promedio diaria.

that the program to control ozone was successful and met the goal set then.

The present study is a continuation of the previuos one and it encompasses data from 2000 to 2006 for the five stations described previously

The five meteorological stations considered have the following geographical coordinates:

\begin{tabular}{|c|c|c|}
\hline Tlal & $19^{\circ} 31^{\prime} 4$ & $99^{\circ}$ \\
\hline Xalc & $19^{\circ} 31^{\prime}$ & 1" W. Long. \\
\hline Ier & $19^{\circ} 25^{\prime} 27.792^{\prime \prime}$ Lat. N. & $97 "$ W. Long. \\
\hline$d$ & $19^{\circ} 19^{\prime} 29.045^{\prime \prime}$ Lat. $\mathrm{N}$ & $99^{\circ} 12^{\prime} 1$ \\
\hline de la Est. & $19^{\circ} 20^{\prime} 09.184$ " Lat. N. & $99^{\circ} 04^{\prime} 28.829^{\prime \prime} \mathrm{W} . \mathrm{L}$ \\
\hline
\end{tabular}

The figure 1 shows de meteorological stations relative position (All the stations are located at $99^{\circ}$ West Longitude and $19^{\circ}$ North Latitude. The longitude as well as the latitude in the figure are in minutes of degree and the horizontal axis is with negative numbers because West longitude increases towards the left):

The distance between meteorological stations in kilometers appears in the table 1:

\section{Recent trend}

The registry of ozone data in the five stations could be considered reliable for comparison purposes, as there is sufficient data, close to the 1825 days in normal years and 1830 in a leap year. The numbers of registered days in the period are given in Table 2. 


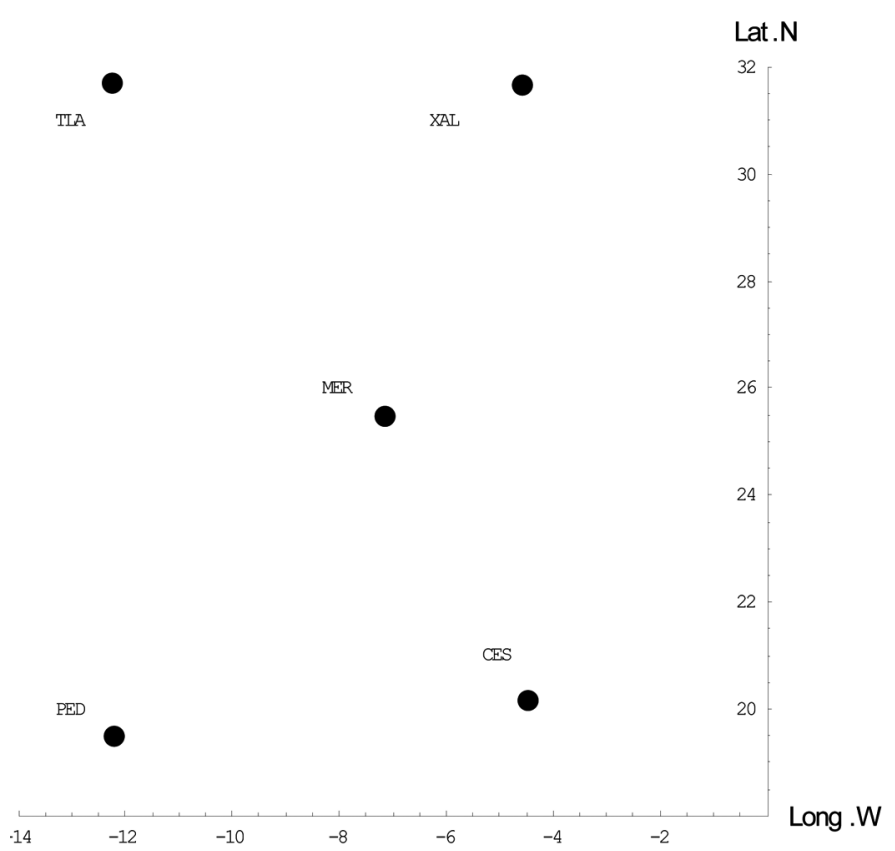

Fig. 1

Table I. Distance between meteorological stations (kilometers).

\begin{tabular}{lllccc}
\hline & CES* & Merced & Pedregal & Tlalnepantla & Xalostoc \\
\hline CES* & 0 & 5.946 & 7.771 & 13.923 & 11.512 \\
Merced & 5.946 & 0 & 7.837 & 8.058 & 6.713 \\
Pedregal & 7.771 & 7.837 & 0 & 12.220 & 14.375 \\
Tlalnepantla & 13.923 & 8.058 & 12.220 & 0 & 7.667 \\
Xalostoc & 11.512 & 6.713 & 14.375 & 7.667 & 0 \\
\hline
\end{tabular}

* Cerro de la Estrella.

Table 2. Number of days in the period 2000-2006 producing ozone data.

\begin{tabular}{lc}
\hline Year & Days registered \\
\hline 2000 & 1801 \\
2001 & 1822 \\
2002 & 1805 \\
2003 & 1809 \\
2004 & 1819 \\
2005 & 1795 \\
2006 & 1815 \\
\hline
\end{tabular}

The media evolution of the daily maximum ozone levels in the group of five stations is illustrated in Figure 2.

In Figure 2 it can be appreciated that the media trend decreases in the whole period, but the decrease is more acute in the first part of the period (2000-2001) than in the final portion (2005-2006). The percentage of days in the 5 stations, in which the norm $110 \mathrm{ppb}$ is exceeded, is another important factor to be analyzed. This is illustrated in Figure 3.

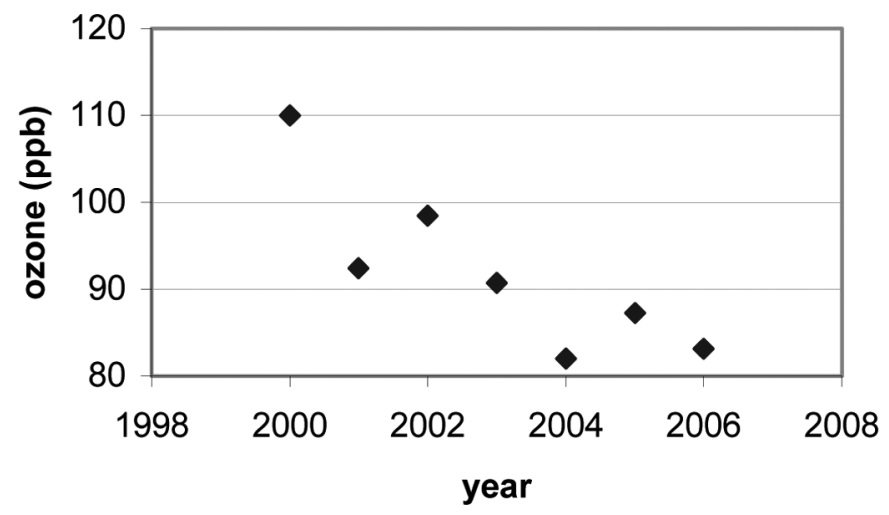

Fig. 2. Yearly mediam of maximum daily ozone.

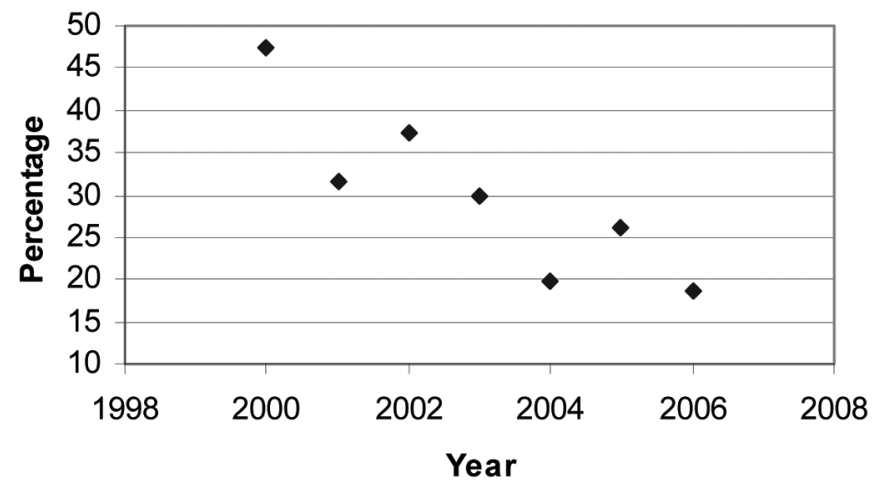

Fig. 3. Porcentage of days exceeding norm.

The maximum daily ozone per year is illustrated in Figure 4. It can be appreciated that the maximum daily ozone lies around a figure of 225 in the last portion of the graph regardless of year.

The hourly ozone data for the 5 stations depict the ozone concentration in the Valley of Mexico is summarized in Table 3.

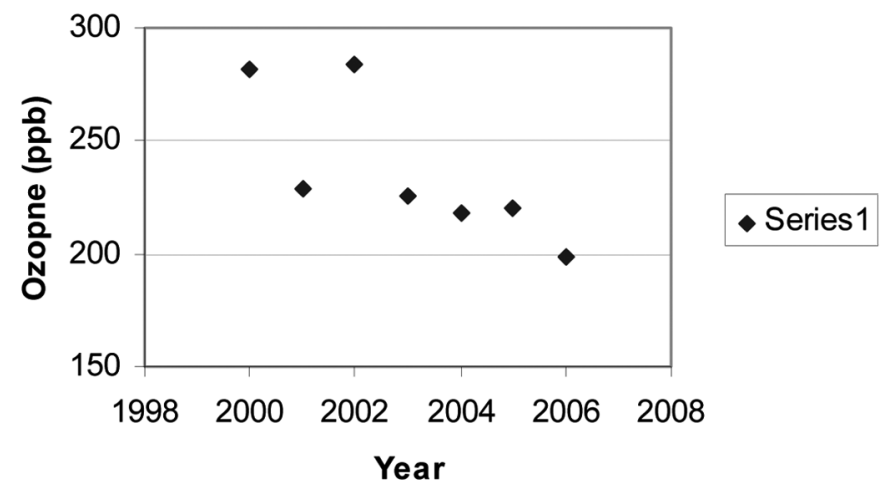

Fig. 4. Maximum daily ozone in the 5 stations. 
Table 3. Ozone concentration (ppb) in the Valley of Mexico (5 stations).

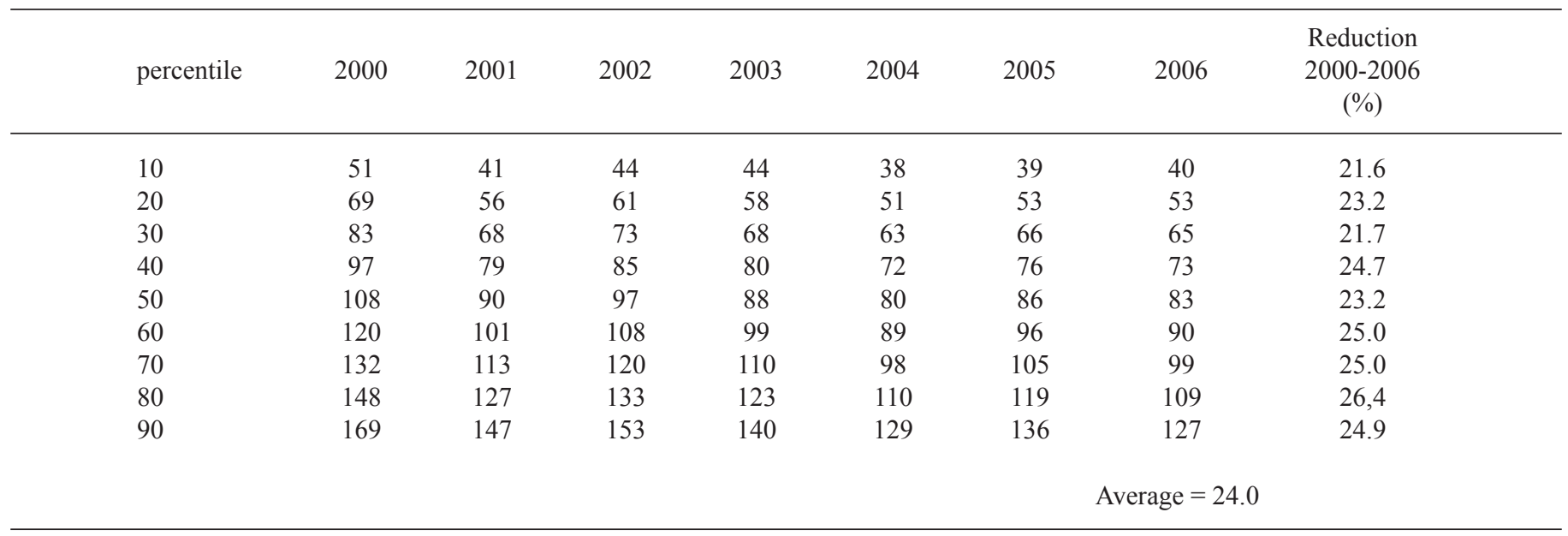

From the data shown in Table 3, it can be concluded that:

- The average ozone reduction in the period 2000-2006 was $24 \%$, which compares favorable and continues the observed trend in 1991-1999 that showed a reduction of $34.4 \%$.

- In the period 1991-1999 the decrease in the ozone concentration was higher in the lower percentiles than in the higher ones. The opposite took place in the period 2000-2006, where the higher ozone reductions took place in the higher percentiles.

With respect to each station, the percentage of days exceeding the ozone norm is shown in Table 4.

Pedregal is the station in which the norm was more often exceeded, as in 2006 the norm was not met in more than $42 \%$ of the days. On the other hand, Xalostoc was the station with the lowest number of days in which the norm was not complied with, as only less than $6 \%$ of the days did not meet the norm in 2006.

From inspection of Figures 3 and Table 3 it can be concluded that the highest ozone concentration in the period was registered in 2000, followed by 2002 .

The distribution of the maximum daily ozone levels for the five stations, from the $10 \%$ percentile to the $90 \%$ is given in Table 3.

\section{Conclusions and Recommendations}

It can be concluded that:

- Ozone levels have been decreasing along the period 2000-2006, but still very often the norm is exceeded, mainly at the Pedregal Station, where they amounted to $42 \%$ of the registered days.

- The worst ozone levels were found in the year 2002 within the period 2000-2006.

- Air quality improved as the years pass, the improvement is more notorius in the higher percentiles than in the lower ones.

\section{Vehicular Fleet}

The trend in ozone levels can not be discussed without considering the number of vehicles circulating in the Metropolitan Zone of Mexico City. In Table 5, it is summarized the number of vehicles registered every two years by the Government of the Federal District.

From Table 5 it can be concluded that:

- Except pick'ups all other type of vehicles have increased in number in the period 2000-2006 by an average of $35 \%$.As ozone is mainly affected by gaso-

Table 4. Yearly percentage of days per station in which the ozone norm is exceeded.

\begin{tabular}{|c|c|c|c|c|c|c|c|}
\hline & 2000 & 2001 & 2002 & 2003 & 2004 & 2005 & 2006 \\
\hline Cerro Est. & 35.9 & 29.7 & 28.2 & 27.9 & 17.3 & 21.5 & 11.2 \\
\hline Merced & 58.6 & 45.7 & 42.1 & 32.5 & 21.3 & 30.4 & 22.5 \\
\hline Pedregal & 73.4 & 41.6 & 67.7 & 51.5 & 34.1 & 48.3 & 42.2 \\
\hline Tlalnepantla & 35.0 & 26.6 & 27.1 & 22.1 & 15.9 & 14.1 & 12.0 \\
\hline Xalostoc & 33.6 & 14.4 & 20.8 & 15.5 & 10.1 & 14.6 & 5.7 \\
\hline
\end{tabular}


Table 5. Vehicular Fleet circulating in the Metropolitan Area of Mexico City.

\begin{tabular}{lrrrrrr}
\hline Type & 1994 & 1996 & 1998 & 2000 & 2002 & 2004 \\
\hline private car & $1,969.277$ & $1,947,464$ & $2,147,448$ & $2,364,031$ & $2,722,080$ & $2,967,893$ \\
taxi & 69,745 & 92,222 & 96,639 & 109,792 & 112,452 & 118,634 \\
combi & 20,963 & 20,963 & 20,820 & 19,825 & 19,700 & $19,275,567$ \\
microbus & 32,346 & 32,346 & 31,590 & 31,949 & 30,757 & 33,126 \\
Pick up & 153,916 & 146.748 & 148,896 & 145,846 & 151,218 & 128,281 \\
$<3$ ton & 48,172 & 49,189 & 50,572 & 53,607 & 61,494 & 62,543 \\
Tract bus & 49,667 & 53,333 & 51,017 & 62,886 & 75,575 & 83,034 \\
bus & 23,561 & 23,829 & 22,884 & 24,896 & 30.656 & 32,419 \\
$>3$ ton & 52,730 & 51,934 & 51,584 & 52,804 & 56,744 & 86,3613 \\
motorcycle & 37,667 & 54,408 & 73,869 & 96,703 & 102,499 & 57,913 \\
Total & $2,458,944$ & $2,472,436$ & $2,697,317$ & $2,964,339$ & $3,363,175$ & 127,454 \\
\hline
\end{tabular}

Source: Secretaría del Medio Ambiente del GDF.

Table 6. Gasoline consumption in the Metropolitan Area of Mexico City (millions of liters per day).

\begin{tabular}{lrrrrrrr}
\hline & 2000 & 2001 & 2002 & 2003 & 2004 & 2005 & 2006 \\
\hline PEMEX Magna & 16.4 & 16.4 & 16.1 & 16.0 & 16.2 & 16.6 & 18.1 \\
PEMEX Premium & 1.75 & 2.0 & 2.4 & 2.7 & 2.8 & 2.7 & 2.9 \\
Total & 18.2 & 18.4 & 18.5 & 18.7 & 19.0 & 19.3 & 21.0 \\
\hline
\end{tabular}

Source: Petróleos Mexicanos

line driven vehicles, it is convenient to analyze the consumption of gasoline in the period, information which is given in Table 6 .

- In Table 6 , it can be appreciated a yearly increase in gasoline consumption, which amounts to $15.7 \%$ in the period. The higher quality gasoline, the PEMEX Premium had an increase of $64 \%$ in the period, which is indicative of the preference shown by the owners of new cars, to use PEMEX Premium.

- The ozone reduction is slightly higher in the higher percentiles. As the regions showing higher ozone levels are where the most affluent society resides, it could be inferred that the rate of car replacement for most modern and less contaminating vehicles is higher in wealthy regions than in lesser ones.

- As the volume of gasoline used in the Valley of Mexico of 20 millions of liters a day is high, it is advisable to improve gasoline quality by reducing the Reid Pressure to $7 \mathrm{psig}$, in order to decrease the gasoline lost by evaporation richer in olefins (2).

- Another factor that is required to analyze to reach firm conclusions is the temperature profile in the five stations aforementioned, as ozone formation is also temperature dependant. Unfortunately there is not a full registry of the temperature profile in the 5 stations that represent the Metropolitan Area of Mexico City.
The relation between temperature and ozone concentration is a very strong one. The following plot shows de hourly concentration of ozone and temperature normalized for the first six days of 1999 in the Pedregal metereological station. (the normalization of both: ozone and temperature was done substracting the mean value form the series and dividing by the standard deviation of the corresponding series. The mean of the ozone is $0.05388 \mathrm{ppm}$ and the mean of the temperature $16.322^{\circ} \mathrm{C}$. The standard deviation for the already substracted series are 0.05236 and 5.411 for ozone and temperaure respectively).

Hourly profiles for ozone and temperature pedregal 1999

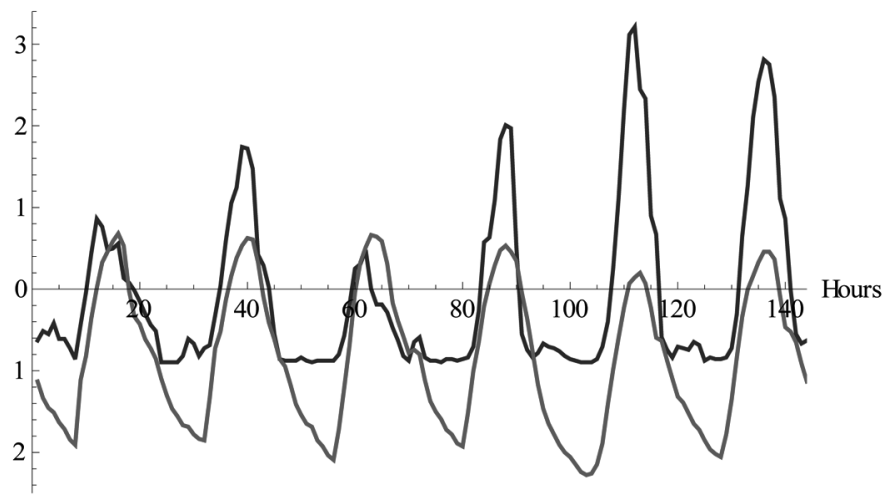

Fig. 5. Hourly profiles of ozone and temperature for six days 
The most sharp peaks correspond to de ozone plot. A better relationship between de temperature and ozono behavior is obtained considering the mean values along the year. The next plot (Figure 6) shows the hourly average of temperature and ozone normalized (normalization was acomplished as in the previous plot. The means are $0.0363 \mathrm{ppm}$ and $16.74^{\circ} \mathrm{C}$ for ozone and temperature respectively. The standard deviations are $0.02928 \mathrm{ppm}$ and $4.68^{\circ} \mathrm{C}$ for ozone and temperature respectively) for the full year of 2005 in Pedregal meteorological station. The sharpest peak is for ozone

Mean hourly temperature and ozone pedregal 2005

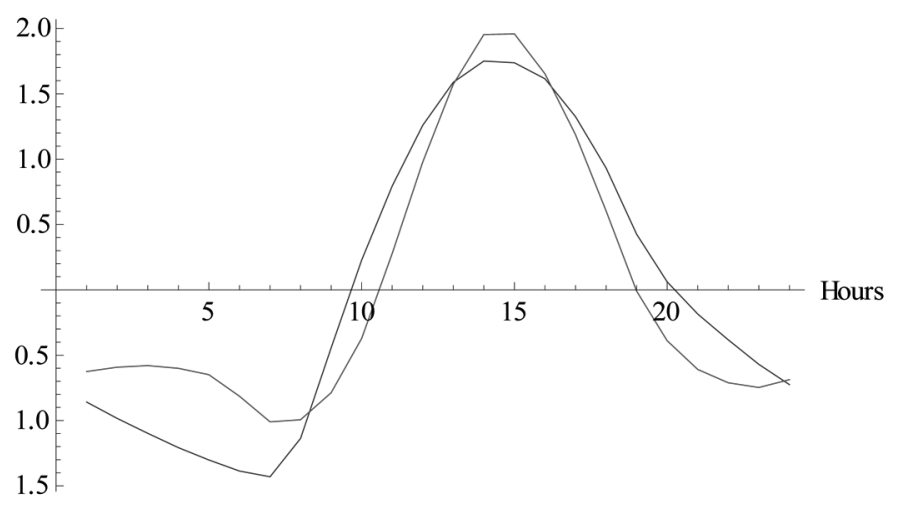

Fig. 6.

the same plot for the temperature and ozone for 2004 is the following (means of temperature and ozone are: $16.05^{\circ} \mathrm{C}$ and $0.0308 \mathrm{ppm}$. The standard deviations are $4.18^{\circ} \mathrm{C}$ and 0.0264 ppm):

Mean hourly temperature and ozone pedregal 2004

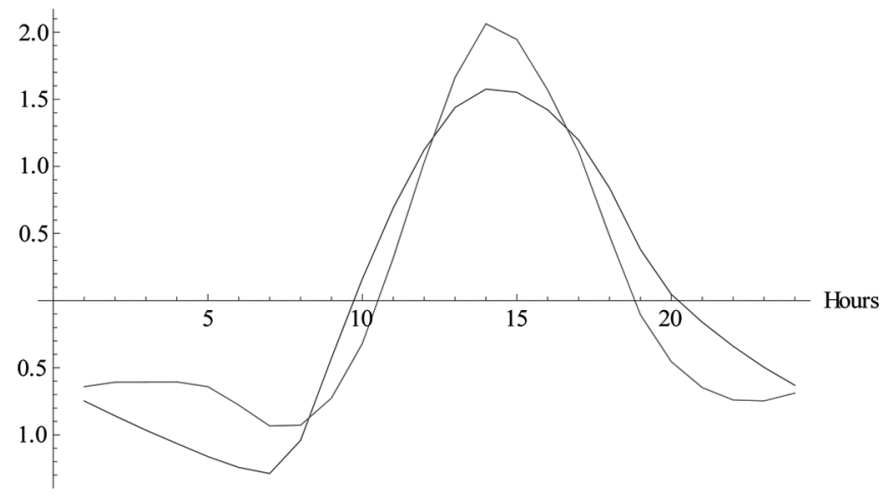

Fig. 7.

The plot comparing the normalized hourly temperatures for 2004 and 2005 for the same meteorological stations is:
Mean hourly temperature in 2004 and 2005 pedregal 2005

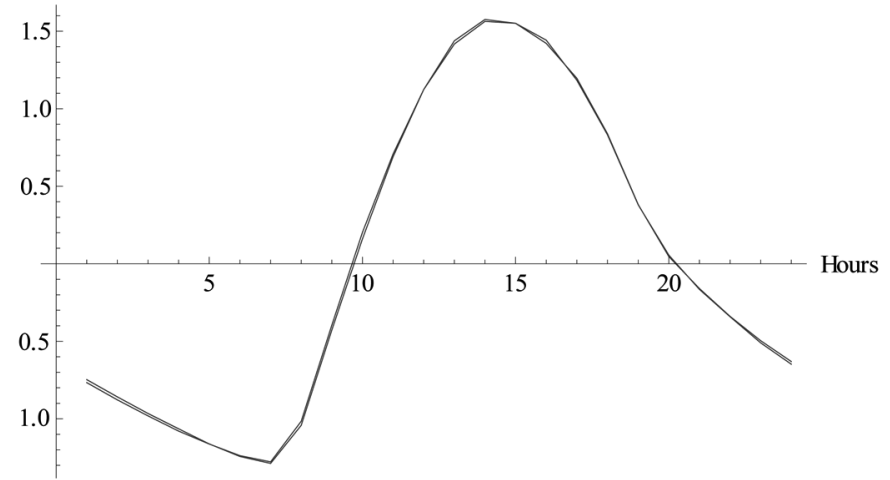

Fig. 8.

Both curves are almost identical.

Similarly the plots of mean yearly hourly for ozone for 2004 and 2005 given in the next figure almost coincide, which means that temperature was not a factor for air quality improvement.

Normalized mean yearly hourly ozone pedregal 2004, 2005

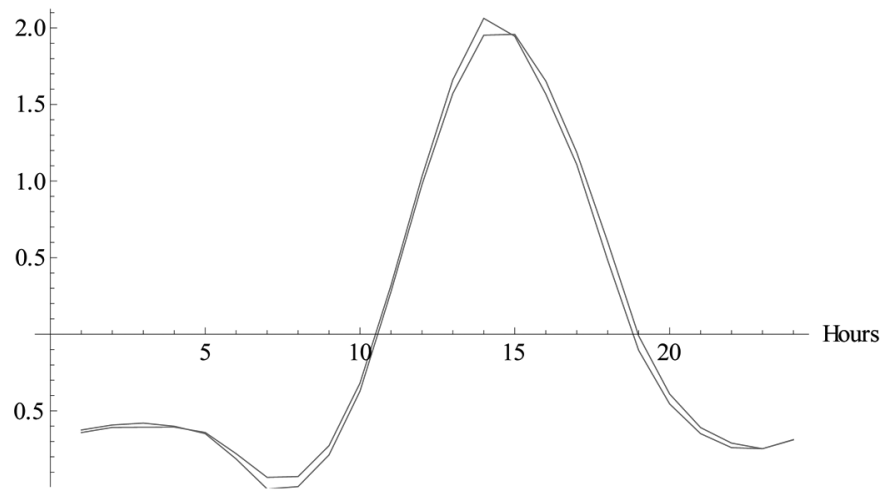

Fig. 9.

- It is recommended to have more reliable statistics as to the number of cars circulating in Mexico City, as the owners of old cars seem to maintain its registration even if they posses and only use the newly acquired cars.

- It can be concluded that the rate of change of old cars by new ones and less contaminating ones, has decreased the ozone levels in Mexico City. However, the problem still subsists in the area close to the Pedregal Station, where the norm is exceeded $42 \%$ of days.

- There is no doubt that as far as ozone is concerned, air quality in the Valley of Mexico has improved considerably. In order to better understand the reason for the improvement, it is convenient to consider jointly 
the evolution of the vehicular fleet and gasoline consumption. If it is assumed that the whole set of private cars, taxis, combis, pick ups and motorcycles consume gasoline and if it is supposed that the distance traveled by the gasoline powered vehicles is constant in time, this is, that not withstanding the year, the total distance run by the vehicular fleet is the same, then it is possible to calculate an average figure for the liters per day consumed per vehicle for the years 2000, 2002, 2004 and 2006. The figures arrived at, are given in Table 7. The figures obtained are 6.64 for 2000; 5.96 for 2002; 5.64 for 2004; and 5.61 for 2006. It should be said that not necessarily the vehicles registered are those that circulate, as the owner of a new car shows preference to drive the new car rather than the older car. However, both cars are registered.

Table 7. Average gasoline consumption per day for the vehicular fleet in the Valley of Mexico

\begin{tabular}{lcccc}
\hline & 2000 & 2002 & 2004 & 2006 \\
\hline $\begin{array}{l}\text { Vehicles } \\
\text { Total daily gasoline }\end{array}$ & $2,736,197$ & $3,107,949$ & $3,361,747$ & $3,741,244$ \\
$\begin{array}{l}\text { consumption }\left(1 \cdot 10^{-3}\right) \\
\begin{array}{l}\text { Daily vehicular } \\
\text { consumption (1/day) }\end{array}\end{array}$ & 6.64 & 5.96 & 5.64 & 5.61 \\
\hline
\end{tabular}

- One would expect that the higher number of cars circulating would require an incremental volume of gasoline consumption. However, in spite of an increment in time on the number of units comprising the vehicular fleet, the gasoline consumption per unit has decreased, which indicates that there has been an increase in the efficiency of the vehicular fleet, by the incorporation of new models. An increase in efficiency means that the vehicles are less contaminating, disregarding the type of gasoline consumed. The relative volume increase in Premium over Magna would involve lesser emission of particles, as Premium has lower sulfur content than Magna, but as regards as the ozone precursors there should not be much difference between both fuels.
The relative volume increase in the demand of Premium over Magna confirms that there has been a car renewal, circulating now newer and more efficient cars than the older inefficient ones.

It seems to be that the increase trend in efficiency is approximating to a minimum and is not expected to a further spectacular increase in efficiency, as the figure reached in 2004 of 5.64 is close to 5.61 of 2006, unless a new policy is implemented to favor 4 cylinder cars over 6 or 8 cylinders ones.

On the other hand, in a survey conducted by one of the authors (3) it was found that the average daily consumption by a taxi was 18 liters. The taxi fleet in 2000 was 109972 vehicles, which gives a total daily consumption of nearly 2 million liters, which is approximately $11 \%$ of total. If in top of that it is added the gasoline used by combis and buses, it is realized the importance that must be given to the Inspection and Maintenance Programs for the sector of public transportation.

Recently, some discussion has arisen upon the convenience to install the program to avoid vehicle circulation on Saturdays to improve air quality in Mexico City. We have no solid arguments to favor or oppose such a program, but from the ozone viewpoint, it is convenient to look at the average ozone levels during the different days of the week, to see if a lower ozone level on Saturday brings down an ozone level on another day.

In Table 7, the average ozone levels for the different days of the week are shown for the stations of Pedregal, Merced and Tlalnepantla for 2006.

In the following graphs the data in Table 7 are illustrated as follows:. average ozone levels during weekdays at
Pedregal Stration

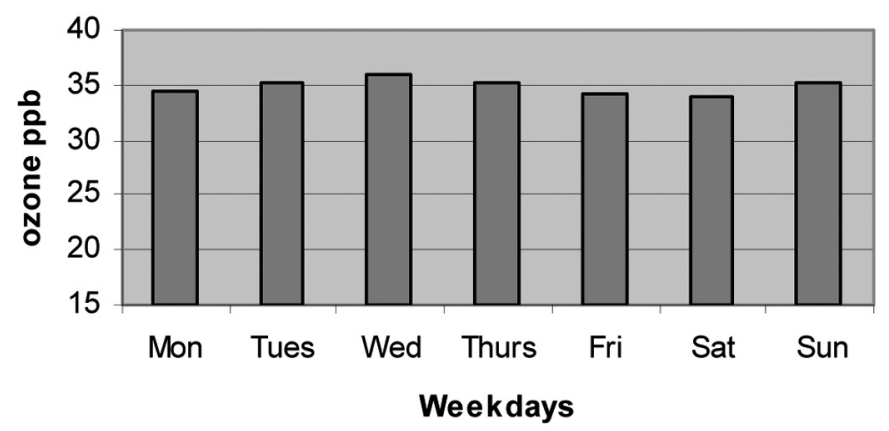

Table 7. Average ozone levels (ppb) for different days of week in Mexico City in 2006

\begin{tabular}{lcccccc}
\hline Station & Monday & Tuesday & Wednesday & Thursday & Friday & Saturday \\
\hline Pedregal & 34.373 & 35.313 & 35.866 & 35.305 & 34.279 & 33.978 \\
Merced & 24.995 & 25.333 & 26.236 & 25.862 & 24.989 & 24.839 \\
Tlalnepantla & 26.918 & 26.572 & 27.826 & 28.010 & 27.556 & 27.472 \\
\end{tabular}




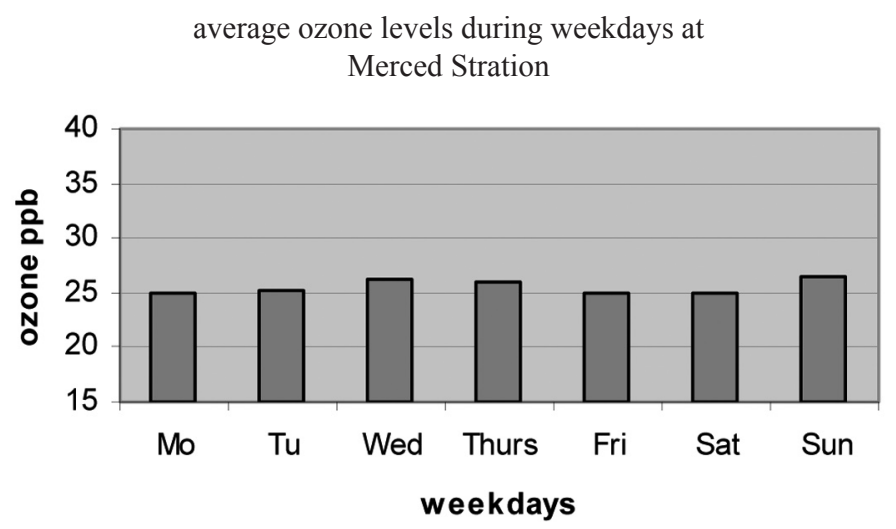

As expected, in general the worst ozone level is at Pedregal, with an average of $35 \mathrm{ppb}$. It is also seen that in general the worst ozone day on average is on Wednesday, and the lowest ozone level occurs on Saturday, and the low Saturday level does not reflect on the Sunday level, as in one station (Merced), the average ozone level is even the worst during the whole week. It must be said, that temperature is the factor that has most influence on ozone formation, so an analysis of temperature profiles among the weekdays would give a better idea as to the improvement on air quality by curtailing car circulation on Saturdays. average ozone levels during weekdays at Tlalnepantla Stration

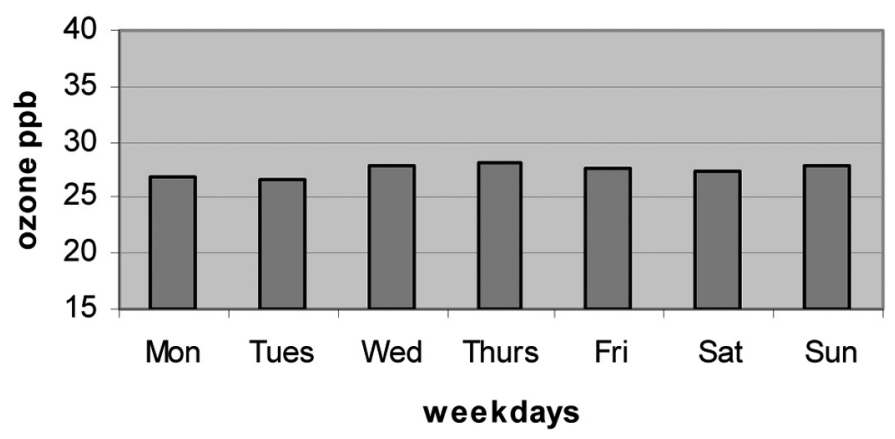

\section{References}

1. Garfias Ayala, F. J.; and Díaz Gutiérrez L., «Gasolinas Oxigenadas: The Mexican Experience», Fondo de Cultura Económica, México. 2003.

2. Garfias, F. J.; Huesca, R. La gasolina del Valle de México, p. 1 in «Contaminación Atmosférica III» by García Colín Leopoldo y Varela Ham Juan Rubén, El Colegio Nacional, México. 2001.

3. Personal survey conducted by Javier Audry Sánchez. 2007. 